\title{
Methods Course for Primary Level STEM Preservice Teachers: Constructing Integrated STEM Teaching
}

\author{
Pattamaporn Pimthong ${ }^{1 *}, \mathrm{P}$ John Williams ${ }^{2}$ \\ ${ }^{1}$ Faculty of Education, Kasetsart University, Bangkok, THAILAND \\ ${ }^{2}$ School of Education, Curtin University, Perth, AUSTRALIA
}

Received 10 January $2021 \cdot$ Accepted 2 July 2021

\begin{abstract}
A STEM methods course was developed for undergraduate preservice teachers at the faculty of education. The course model design had three phases: 1) review of the STEM literature and conceptual considerations, 2) planning of the STEM methods course, and 3) evaluation by experts and revision based on their feedback. Research literature and other documentation were reviewed. A framework and guiding principles for primary-level STEM education were developed to identify key elements, including STEM focus/essence, student-centered, curriculum, learning environment, and assessment. A 15-week STEM methods course was planned to model good practices for teaching integrated STEM and to let preservice teachers confront real-world issues and problems that arise in STEM instruction and then design their own STEM lessons or activities for teaching. The result of implementing the STEM methods course was examined through preand post-surveys which showed the influence of the methods course in promoting preservice teachers' STEM understanding.
\end{abstract}

Keywords: STEM education, STEM methods course, preservice teacher, design model

\section{INTRODUCTION}

As in other countries, the Thai government is promoting education in science, technology, engineering, and mathematics (STEM) at all educational levels to increase the number of students in STEM programs and to increase performance on international science and mathematics tests (Chulavatnatol, 2013). STEM education is considered necessary to prepare Thai students for an inclusive society that requires everyone to have the personal and social skills to work collaboratively with individuals grounded in a wide range of disciplines (The National News Bureau of Thailand, 2017). STEM can help release Thailand from its current middle-income trap by promoting technological development and innovation through a STEM workforce that will increase productivity and innovation by exploiting the country's comparative advantage in biological and cultural diversity (National Science Technology and Innovation Policy Office, 2015; Office of the Prime Minister, 2017; Royal Thai Embassy, 2017). STEM education projects are being promoted in schools and universities throughout Thailand with the support of the National STEM Education Center and Regional STEM Education Centers, which are acting as teacher development centers to prepare exemplary STEM support material and conduct teacher training (The Institute for the Promotion of Teaching Science and Technology [IPST], 2017).

Although STEM education is receiving much official encouragement in Thailand, teacher education remains inadequate. Preservice teachers from single disciplines for example, preservice physics teachers or preservice mathematics teachers are expected to teach STEM after graduating. STEM education is not emphasized in preservice teacher programs; it is simply one among other topics in some courses. Preservice teachers have no opportunity to study or design lessons or practice STEM teaching. The results of a preliminary study showed that most preservice teachers had an inadequate understanding of the nature and practical aspects of STEM education. Although most were aware of the promotion by the government of STEM education, they could not coherently articulate its goals (Pimthong \& Williams, 2020). Other studies have shown the need for

(c) 2021 by the authors; licensee Modestum. This article is an open access article distributed under the terms and conditions of the Creative Commons Attribution License (http://creativecommons.org/licenses/by/4.0/). 


\section{Contribution to the literature}

- The study presents the framework and guiding principles for developing a STEM methods course for undergraduate preservice teachers.

- This study highlights integrated STEM as the main philosophical concept for developing a STEM methods course for undergraduate preservice teachers.

- The study contributes literature related to STEM, STEM education, integrated STEM and STEM preservice teacher preparation.

effective preservice STEM preparation programs in preparing quality STEM teachers (Bartels et al., 2019; Bell, 2016; English, 2017; Nadelson et al., 2013; Schmidt \& Fulton, 2016; Shernoff et al., 2017).

Preliminary study investigated the understanding of STEM education among 87 preservice teachers with different specializations at the faculty of education of a university in Bangkok, Thailand (Pimthong \& Williams, 2020). Although 77 of the participants indicated that the purpose of STEM education was to develop the ability to use STEM in everyday life, a range of perspectives were represented. STEM integration was mentioned by 20 participants, but none described how the four disciplines were integrated. Instead, the focus fell on the integration outcomes, such as problem-solving ability, projects, and innovations. The preservice teachers' ideas about the importance of STEM varied based on their major area of study. Most of them were aware of STEM because they viewed their major as a part of STEM, especially regarding content knowledge. This preliminary study indicated the importance of promoting understanding by preservice teachers of the integrated nature of STEM and the connections among the disciplines. The study concluded that preparation programs for teaching STEM should be different from science, technology or mathematics preparation programs because it represents the integration of disciplines. Furthermore, the preservice teachers need support to understand the ideas of integrated STEM as well as the identity of each discipline.

However, there is no STEM preparation program in undergraduate preservice teacher education in Thailand. There are many the Bachelor of Education programs in teaching science or physics or chemistry or mathematics but not teaching STEM. The STEM methods course may help the preservice teacher majoring in S-T-E-M to understand and teach STEM. This study investigated how a STEM methods course could be designed for preservice teachers preparing to be STEM teachers.

\section{Concept of STEM and STEM Education}

STEM represents the integration of science, technology, engineering, and mathematics. The term was developed in the 1990s at the Interagency Meeting on Science Education at the National Science Foundation (NSF) in the United States. The initial rationale for a
STEM focus was a general deficiency of everyday knowledge of science, technology, and mathematics, and that American test scores were behind those of students in other industrialized nations in these subjects. Scientific and technological innovation has increased in importance since then, therefore, developing students' STEM capabilities is necessary to enable them to succeed in the contemporary information-based and highly technological society. A need for a greater emphasis on STEM existed in the US education system at all levels (NSF, 2007). American students were expected to achieve high scores on international tests to show the ability of the United States to remain competitive in the world. The United States government is supporting the STEM education policy and investment to promote students' scores and help the students ready for future education and STEM careers (Kocabas et al., 2019). Many countries have similar problems to the US related to the changing nature of technology and society, international assessments such as TIMMS and PISA, and the decreasing number of students who are interested in science and technology. STEM is not only important for those who need to understand the application of STEM in their work, but it is also important for everyone to understand STEM and have multidimensional capabilities to use in everyday life. STEM in this perspective is related to educating people to be ready for living in a STEM-related world where disciplines are interdependent because there are complex and multidimensional issues and problems (Bybee, 2013; English, 2017; Kelley \& Knowles, 2016; National Research Council, 2011; Radloff \& Guzey, 2016; Talley, 2017; Vasquez et al., 2013).

"STEM literacy for all" is an important idea which indicates that STEM education should be accessible by all (English, 2017) in order to: encourage literacy and competency in understanding STEM related national and global issues; recognize scientific from non-scientific explanations; make reasonable arguments based on evidence; and fulfil civic duties at the local, national and global levels (Bybee, 2013). Over the past decade, STEM education has remained a goal of education for many countries to prepare their citizens for life and to be part of the STEM workforce (National Research Council, 2011; Prinsley \& Johnston, 2015; The Institute for the Promotion of Teaching Science and Technology, 2017). 
This study defined STEM as integrated science, technology, engineering and mathematics, arising from the need for competencies to address transdisciplinary complex problems or situations in everyday life.

\section{Integrated STEM}

Integrated STEM is relevant to solve authentic problems or issues that cannot be resolved using a single discipline. The STEM disciplines each have varying natures and worldviews. Science provides explanations of the natural world based on evidence produced in investigations (American Association for the Advancement of Science, 1990; National Research Council, 1996, 2000; Sherman \& Sherman, 2004). Mathematics, which is the study of number, shape, quantity, structure, space, and change, uses reasoning and is conducted with a system of symbols and rules (Hess \& Hess, 2013; The Cambridge english dictionary, 2018), and problem-solving is fundamental to it (Ganado, 2016). Technology and engineering are closely related as both take design as a fundamental process and goal. They develop a designed world to satisfy human needs and wants, and create solutions to problems (International Technology Education Association, 2007; Williams, 2011). Engineering incorporates scientific and technological knowledge to solve problems and promote human capacity to build things (National Academy of Engineering and National Research Council, 2009; Urban \& Falvo, 2016).

Global changes in technology, economy, and society have produced numerous complicated questions, solutions to which require interdisciplinary knowledge and skills. STEM education is well placed to prepare students for STEM careers and life in an increasingly complex world (Bybee, 2013). However, there are some elements of the disciplines that do not lend themselves to be taught in an integrated way, so integrated STEM will never replace these four disciplines. Radloff and Guzey (2016) showed that, in relation to educators, STEM can be thought of as a set of integrated or interconnected disciplines. However, it could also be defined in other ways, depending on specific stakeholders or the context in which it is being viewed or conceptualized. Vasques et al. (2013), and Bybee (2013) both consider that integration may begin with two or more disciplines and agree that a transdisciplinary approach is the end goal to strive for through integrated STEM.

Studies have produced ambiguous results regarding STEM integration. For example, Johnson (2013) commented on a STEM-enhanced model popular in the United States. This model has two versions. The first regards the addition of standalone STEM courses for students. The second relates to the addition of an interdisciplinary, STEM-focused course within the elective courses, not related to the core curricula. This approach serves the needs of schools that are generally concerned with student achievement on assessment tests but ignores STEM skills. Another study by Stohlmann et al. (2011) reported on the Minnesota Middle School Interdisciplinary STEM program (Gateway to Technology, developed by Project Lead the Way [PLTW]) and found unclear outcomes from integration. Mathematics was not explicitly integrated into the curriculum, and insufficient amounts of science and engineering appeared in it.

Many educators have used various models to describe STEM integration. The idea of integrating STEM disciplines is not new (e.g., Sanders, 2009; Urban \& Falvo, 2016); however, integration models vary. For example, Nadelson and Seifert noted that "integrated STEM involves conditions that require the application of knowledge and practices from multiple STEM disciplines to learn about or solve transdisciplinary problems" (Nadelson \& Seifert, 2017, p. 221). They illustrated the degree of an integrated STEM education that segregates STEM at one end of the spectrum and integrates its parts at the other. They indicated differences in the level of knowledge, level of inquiry, structure of activity, level of thinking, and students' competence along the spectrum. Integrated STEM relates to the ways that the knowledge and practices of specific STEM disciplines work together in a problem context, project, or task in the seamless amalgamation of the content and concepts of STEM disciplines. They promoted a mixture of segregated foundational knowledge of STEM with integrated project-based STEM because STEM instruction at school tends to be at the segregated end of the spectrum, where the knowledge is foundational, typified by direct instruction, and content-focused.

To illustrate how the disciplines are integrated with each other, a framework was developed for integrated STEM education. Kelley and Knowles (2016) described the integration of two or more disciplines as integrated STEM education. They defined integrated STEM education as "the approach to teaching the STEM content of two or more STEM domains, bound by STEM practices within an authentic context for the purpose of connecting these subjects to enhance student learning" (Kelley \& Knowles, 2016, p. 3).

However, Sanders rejected the term STEM education, calling it misused and a "hopelessly ambiguous phase" (Sanders, 2012, p. 2, 2015). He recalled that the NSF first used STEM to refer to four separate and distinct fields. He argued that STEM education should simply entail bringing four disciplines together. He described his work with colleagues on what they called integrative STEM education, not merely STEM education, describing it as "approaches that explore teaching and learning between/among any two or more of the STEM subject areas, and/or between a STEM subject and one or more other school subjects" (Sanders, 2009, p. 21). This would make STEM "purposeful design and inquiry" 
(2009, p. 21), in a pedagogy that combines technological design with scientific inquiry to engage students in scientific inquiry situated in the context of technological problem-solving. In such a pedagogy, mathematics is also used for technological design and problem-solving. Sanders (2013, 2015) defined integrative STEM education as a "technological/engineering design-based learning approach that intentionally integrates content and process of science and/or mathematics education with concept and process of technology and/or engineering education. Integrative STEM education may be enhanced through further integration with other school subjects, such as language arts, social studies, art, etc. (Sanders \& Wells, 2010)." More recently, this definition of integrative STEM education was adopted at Virginia Polytechnic Institute and State University (Virginia Tech), whose website describes "the application of technological/engineering design based pedagogical approaches to intentionally teach content and practices of science and mathematics education through the content and practices of technology/engineering education. Integrative STEM Education is equally applicable at the natural intersections of learning within the continuum of content areas, educational environments, and academic levels (Wells and Ernst 2012/2015; Virginia Tech, 2018)."

Sanders $(2013,2015)$ and Urban and Falvo (2016) differ in how they assign the location of and relationship between technology and engineering. Sanders (2013, 2015) brings together technology and engineering. However, Urban and Falvo (2016) considered engineering to be a single discipline that can integrate with other disciplines. Nonetheless, all found that the integration of STEM disciplines was more important than just bringing one discipline into another without deeply understanding the content and processes of each. Integration can only occur with a focus on both content knowledge and interdisciplinary processes.

\section{STEM Preservice Teacher Preparation}

This study investigated the development of STEM understanding and pedagogical knowledge. Preservice teachers must have a clear understanding of interdisciplinary processes of the four parts of integrated STEM and have the capability to teach STEM. This understanding is very important because it relates to the effectiveness of their STEM teaching to promote STEM understanding in their students (Bell, 2016).

STEM education in classrooms promotes agency among young children who are naturally ready to inquire, design, create, and problem solve (Lópezleiva et al., 2016). Much research suggests students should engage with STEM while they are young to prompt and maintain their interest throughout schooling (English 2017; Koul et al., 2016; Murphy, 2011; Park et al., 2016; Prinsley \& Johnston, 2015). Primary school teachers need to understand STEM integration of the core disciplines based on real-world contexts by preparing welldesigned STEM activities that promote student-centered learning (English, 2016, 2017). Those who teach STEM are key to implementing STEM education in classrooms (Johnson et al., 2016; Sias et al., 2017). Teachers must have STEM understanding and pedagogical content knowledge to promote important skills and knowledge in STEM and demonstrate how it relates to daily life and careers. Producing integrated approaches in STEM can be challenging (Shernoff et al., 2017; Stohlmann et al., 2011).

Preservice teacher preparation programs are important for developing an understanding of STEM knowledge, integrated STEM, and pedagogical practices that support STEM integration (Radloff \& Guzey, 2016; Shernoff et al., 2017). Oliva $(1982,2009)$ proposed 12 components and 2 phases of curriculum development and instruction to promote an interdisciplinary curriculum by specifying the need for curriculum goals and objectives that relate to students' and society's needs, selecting and implementing strategies and evaluation techniques, and evaluating instruction and curricula. Because course design is part of curriculum design, it must also needs to account for student needs, set objectives, plan courses, implement them, evaluate them, and revise them (Ahn et al., 2009; Lovell-Troy \& Eickmann, 1992; Posner \& Rudnitsky, 1994)

The STEM methods course in this study is based on the guides and activities which are related to STEM understanding:

1. STEM preservice teachers need to understand the concept of integration and how to teach S-T-E-M, not as a silo approach.

2. The preservice teachers need to have some background in STEM disciplines, both content knowledge and process. They need to be shown the core content knowledge of each discipline and the interdisciplinary processes which are interweaving among the main four disciplines.

3. The purposes of STEM education need to be clear for the preservice teachers, based on the educational goals.

4. The STEM teacher preparation program should be different from science, technology or mathematics teacher preparation programs because it integrates disciplines.

The preservice teachers need support to understand the ideas of integrated STEM and the identity of each discipline.

\section{METHODS}

This STEM methods course was modeled on constructivism, and learning was considered to involve individually and socially constructed knowledge. 


\section{- STEM Course Design Model -}

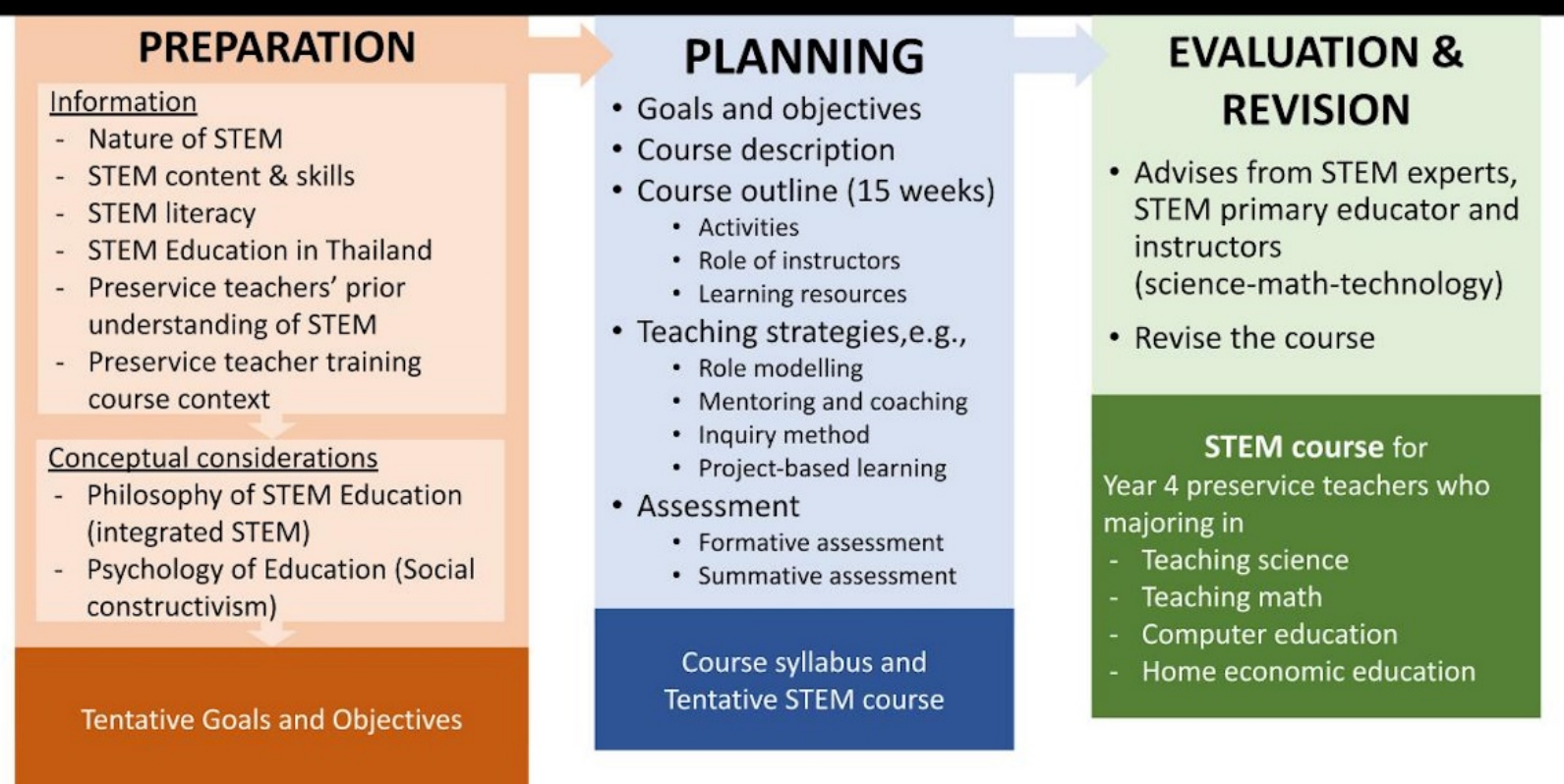

Figure 1. STEM course design model

Individuals hold differing ideas and develop them by participating in social processes that include interaction with others (Bell, 1993; Driver et al., 1994). The course model for STEM methods is a specific model for this process derived from theories of curriculum development and practices and models of course design (Ahn et al., 2009; Lovell-Troy \& Eickmann, 1992; Oliva, 1982, 2009; Posner \& Rudnitsky, 1994). The model for the STEM methods course design incorporates three phases. In the preparation phase, the goals and objectives of the course were developed by surveying the STEM literature and preservice teachers' prior understanding of STEM. In the planning phase, the organization of the course, course syllabus, and detailed activities were developed. Finally, the evaluation and revision phase involved expert critique and revisions to the course. The course design model is shown in Figure 1.

The learning activities in this STEM methods course aim to facilitate preservice teachers' construction of their knowledge by collaboratively working with others and participating with experts (instructors or other experts) in practicing STEM teaching, with these experts acting as role models for STEM teaching.

In the evaluation and revision phase, the course was presented to two Australian STEM expert educators (an associate professor in preservice teacher education and digital technology education and a lecturer in technology education), two Thai STEM educators (a science educator at a university with many research publications on STEM education and a science educator from the IPST who has experience in science curriculum development), and a Thai STEM primary teacher (who has experience in STEM teaching and has won awards).
The experts provided feedback to ensure the clarity of the concept of STEM education, the accuracy of the language and its suitability for undergraduate preservice teachers, and the appropriateness and correctness of the course activities. They also provided examples of STEM lessons. Some experts suggested that the definition of STEM, the STEM approach, and the design process used in the methods course be clarified. All experts indicated that the activities in this STEM methods course would be suitable for undergraduate preservice teachers. However, some experts said that drawing a closer connection between the course activities and the Thai Basic Education Core Curriculum would be important. They suggested that the preservice teachers should examine and critically analyze the purposes and outcomes of each discipline in the curriculum and identify how the STEM disciplines are to be integrated. Following the experts' feedback, the definition of STEM and the STEM approach was clarified. A description of the design process as a fundamental aspect in both technology and engineering was developed. The relationship between technology and engineering was clarified. It includes technology covering the knowledge and processes used to create the products of human invention. Engineering is a branch of technology and involves designing, within constraints, the human-made world (Honey 2012; International Technology Education Association, 2007). STEM integration brings together understanding the natural world using science and mathematics and solving problems in the designed world using technology and engineering (Honey 2012; Radloff \& Guzey, 2016; Sanders, 2015; Stohlmann et al., 2011). Additional tasks were also prepared to ensure that preservice teachers 
Table 1. Guiding principles for STEM education primary teacher education

\section{Guiding principles for STEM education primary teacher education}

These guiding principles reflect the key elements for teaching STEM and suggests how STEM teachers should act to prepare their teaching

\section{STEM focus/essence}

- the integration of knowledge and processes of science, technology, engineering and mathematics

$\circ$ deep understanding in content knowledge

○ STEM skills e.g., problem solving, collaboration, critical thinking

$\bigcirc$ design is a fundamental process for STEM

- the promotion of students to solve real world problems and satisfy needs and wants by using integrated knowledge and skills

\section{Student- Centered}

- learning activities are based on student interest, prior knowledge and experiences

- students are engaged in self-directed learning

- students participate in lesson planning and assessment processes

\section{Curriculum}

- analyzing content and skills from The Thai Basic Education Core Curriculum in the appropriate grade level

- sharing ideas among teachers to plan the integrated STEM lessons together

- preparing active and hands-on activities which are meaningful to students

\section{Learning Environment}

- engaging students in real life issues or problems which cannot be fully understood or solved by the independent approaches of each discipline

- motivating and supporting students' STEM challenges

- school context and policy

\section{Assessment}

- authentic assessment which is part of the learning process, not an extra activity

- variety of assessment strategies and tools

- feedback from teacher, peers, and self-assessment

could design STEM lessons based on the Thai Basic Education Core Curriculum.

The STEM methods course was implemented with seven preservice teachers from the Faculty of Education in a university in Bangkok, Thailand, in the academic year 2020. All of them majoring in Science teaching and having passed a compulsory science methods course. Data on preservice teachers' STEM understanding were collected using a pre-and post-survey at the beginning and the end of the methods course (the questions adapted from Pimthong \& Williams, 2020) including interviews with participants, observations, and reflective journals. The participants' responses were categorized based on an inductive thematic analysis approach (Joffe, 2012).

\section{RESULTS}

\section{Framework and Guiding Principles for STEM Education}

Vasquez et al. (2013) presented STEM's guiding principles, emphasizing integration related to everyday life, 21st century skills and challenging students to learn. Similarly, Bybee $(2010,2013)$ stated that students should have opportunities to learn how to apply knowledge and skills to multidisciplinary situations one confronts in life. The integration and application of science, technology, engineering, and mathematics (STEM) concepts and skills are required (Stohlmann et al., 2011) to ensure it is meaningful and related students' local and global realworld situations. The guiding principles for STEM education at the primary level and the STEM methods course syllabus were developed based on the above studies and the indicators and core concepts of the science learning area (technology is a strand in the science learning area) and the mathematics learning area (Revised version 2017) according to the Thai Basic Education Core Curriculum 2008.

\section{STEM Methods Course}

The STEM methods course for primary teachers was developed to model good practices for the acquisition of relevant pedagogical content knowledge on integrated STEM education. This can enable preservice teachers to engage in authentic and real-world issues or problems in activities that facilitate their achievement of specific content knowledge in STEM fields and their understanding of interdisciplinary processes and pedagogical knowledge for teaching STEM. This will promote skills development in designing and facilitating STEM learning at the primary level. The methods course was designed to cover 15 weeks (3 hours per week) with one instructor in each of science, technology, and mathematics. These three instructors were facilitators working together through team teaching to demonstrate the value of cooperation and collaboration to enhance learning. The 15-week course outline is presented in Table 2.

The STEM methods course was implemented in the academic year 2020. In the first week, the preservice teachers completed a pre-survey on their STEM understanding. This survey allowed the instructors to better prepare activities to promote the understanding of STEM education. In this period, the concept, purpose, and importance of STEM education were presented in a 
Table 2. Outline of the STEM methods course

\begin{tabular}{|c|c|c|}
\hline Week & Topic & Activities \\
\hline 1. & Concept, purpose, and importance of STEM education & $\begin{array}{l}\text { - Pre-survey of the participants' STEM understanding } \\
\text { - Small-group and whole-class discussions about the concept, } \\
\text { purposes, and importance of STEM education }\end{array}$ \\
\hline 2. & Situations and issues regarding STEM education in Thailand & $\begin{array}{l}\text { Brainstorming on and presenting situations and issues of STEM } \\
\text { education in Thailand }\end{array}$ \\
\hline 3. & $\begin{array}{l}\text { Core curriculum, STEM skills, and STEM literacy: } \\
\text { - Thai Basic Education Core Curriculum in part which related } \\
\text { to STEM } \\
\text { - STEM skills and interdisciplinary processes } \\
\text { - STEM literacy }\end{array}$ & $\begin{array}{l}\text { - Analyzing and making judgments indicating how the Thai } \\
\text { Basic Education Core Curriculum relates to or supports STEM } \\
\text { education } \\
\text { - Identify and practice STEM skills through STEM activities } \\
\text { - Identify and analyze STEM literacy through STEM activities }\end{array}$ \\
\hline 4. & Science in STEM & $\begin{array}{l}\text { Participating in STEM activity, and analyzing and explaining } \\
\text { science in STEM in the Thai Basic Education Core Curriculum }\end{array}$ \\
\hline$\overline{5 .}$ & Technology and engineering in STEM & $\begin{array}{l}\text { Participating in STEM activities, and analyzing and explaining } \\
\text { technology and engineering in STEM in the Thai Basic Education } \\
\text { Core Curriculum }\end{array}$ \\
\hline 6. & Mathematics in STEM & $\begin{array}{l}\text { Participating in STEM activities, and analyzing and explaining } \\
\text { mathematics in STEM in the Thai Basic Education Core } \\
\text { Curriculum }\end{array}$ \\
\hline 7. & Integrated STEM & Brainstorming on and presenting the idea of integrated STEM \\
\hline 8. & $\begin{array}{l}\text { Teaching strategies for developing STEM lessons (project- } \\
\text { based pedagogy) }\end{array}$ & $\begin{array}{l}\text { Project-based pedagogy demonstration } \\
\text { Topic: Creating a school bag }\end{array}$ \\
\hline$\overline{9}$. & $\begin{array}{l}\text { Teaching strategies for developing STEM lessons (design- } \\
\text { based pedagogy) }\end{array}$ & $\begin{array}{l}\text { Design-based pedagogy demonstration } \\
\text { Topic: Keep solar energy within a space }\end{array}$ \\
\hline 10. & $\begin{array}{l}\text { Teaching strategies for developing STEM lessons (inquiry- } \\
\text { based pedagogy) }\end{array}$ & $\begin{array}{l}\text { - Inquiry-based pedagogy demonstration } \\
\text { Topic: How plants grow } \\
\text { - Summarize guiding principles for primary level }\end{array}$ \\
\hline 11. & Assessment of STEM learning & $\begin{array}{l}\text { - Practice of planning assessment for STEM lesson } \\
\text { - Design assessment tools for STEM lesson }\end{array}$ \\
\hline 12. & Design STEM lesson plans (part 1) & $\begin{array}{l}\text { Groups of preservice teachers from different majors design a } \\
\text { STEM lesson plan }\end{array}$ \\
\hline 13. & Design STEM lesson plans (part 2) & Groups of preservice teachers present a lesson plan \\
\hline 14. & Practice STEM teaching in an actual classroom & Groups of preservice teachers practice STEM teaching \\
\hline$\overline{15 .}$ & $\begin{array}{l}\text { - Post-survey of the preservice teacher's STEM understanding } \\
\text { - Reflection and wrap up }\end{array}$ & \\
\hline
\end{tabular}

discussion supported by research papers and documents. The preservice teachers encountered STEM education as integration among the four main disciplines, both in content knowledge and skills, to prepare people to live with complex and multidimensional issues or problems that cannot be solved using a single discipline.

After examining STEM education in general, during the second week, the topic was STEM education in Thailand, as a tool to increase the number of students in science programs, raise the scores of Thai students in international science and mathematics testing, and promote essential skills to allow Thai citizens to live in an inclusive society, in which everyone must work with others. STEM education could help Thailand reach the ultimate goal of developing a value-based economy driven by innovation, technology, and creativity, and enabling all the citizens of Thailand to be competent in the 21 ${ }^{\text {st }}$ century (Chulavatnatol, 2013; Royal Thai Embassy, 2017; The National News Bureau of Thailand, 2017).

In the third week, activities turned to analyzing and judging how the Thai Basic Education Core Curriculum relates to and supports STEM education, although the curriculum separately takes science and mathematics, and STEM is not mentioned in it. Preservice teachers had the opportunity to identify and practice STEM skills and analyze STEM literacy through STEM activities. In the fourth to sixth weeks, the main goal was understanding the core content knowledge and skills in the STEM disciplines. The content knowledge and skills in STEM were introduced with STEM activities to show how each discipline can integrate with others.

The notion of integrated STEM was presented in the seventh week, with the main activity being the discussion of research papers and documents and brainstorming on integrated STEM. During the sixth week, project-based learning was presented because it presented active learning, in which students can simultaneously integrate multiple contents (Edutopia, 2008; Grant, 2002; The Buck Institute for Education, 2014; Thomas, 2000). The preservice teachers were encouraged to collaboratively work to create projects based on reallife problems or questions, mirroring STEM education's goal, in which students can relate their learning to daily life. Research has shown that adopting project-based learning helps students understand the purpose of STEM and promotes their interest in it (Fortus et al., 2005). 
In the seventh week, design-based learning was promoted in a STEM activity that provides opportunities for students to find solutions to real-world problems and construct new knowledge through design activities. The activities promoted deep learning of technical fundamentals and practical skills in the context of realworld design experiences (Clavert \& Paloposki, 2015; Fortus et al., 2005; Vartiainen et al., 2012). The use of design-based learning in STEM to promote STEM knowledge and skills is found in many studies (Honey 2012; King \& English 2016; Won et al., 2015).

In the eighth week, inquiry-based learning was adopted to facilitate STEM education (Crippen \& Archambault, 2012; Schmidt \& Kelter, 2017) by developing students' deep discipline-based thinking (Blessinger \& Carfora, 2015) and encouraging students to perceive STEM as a multidisciplinary approach that can be applied to critical issues in the real world (Crippen \& Archambault, 2012) by proposing explanations based on the evidence derived from their work (National Research Council, 1996). The preservice teachers played the role of the students, and the instructors demonstrated teaching strategies. After three demonstrations, a summary of the guiding principles of STEM education was discussed.

In the eleventh week, the preservice teachers practiced assessment and selection of assessment tools for STEM lessons. In the twelfth and thirteenth weeks, groups of three preservice teachers designed their STEM lesson plans, presented them, and received feedback from the class. Then, in the fourteenth week, the preservice teachers did team teaching, using their lesson plans.

In the final week, a post-survey of preservice teachers' STEM understanding was conducted. The findings showed an increase in STEM understanding after implementing STEM methods course. The graphs shown in Figure 2 record the student's response from pre- and post- surveys.

\section{WHAT IS STEM?}

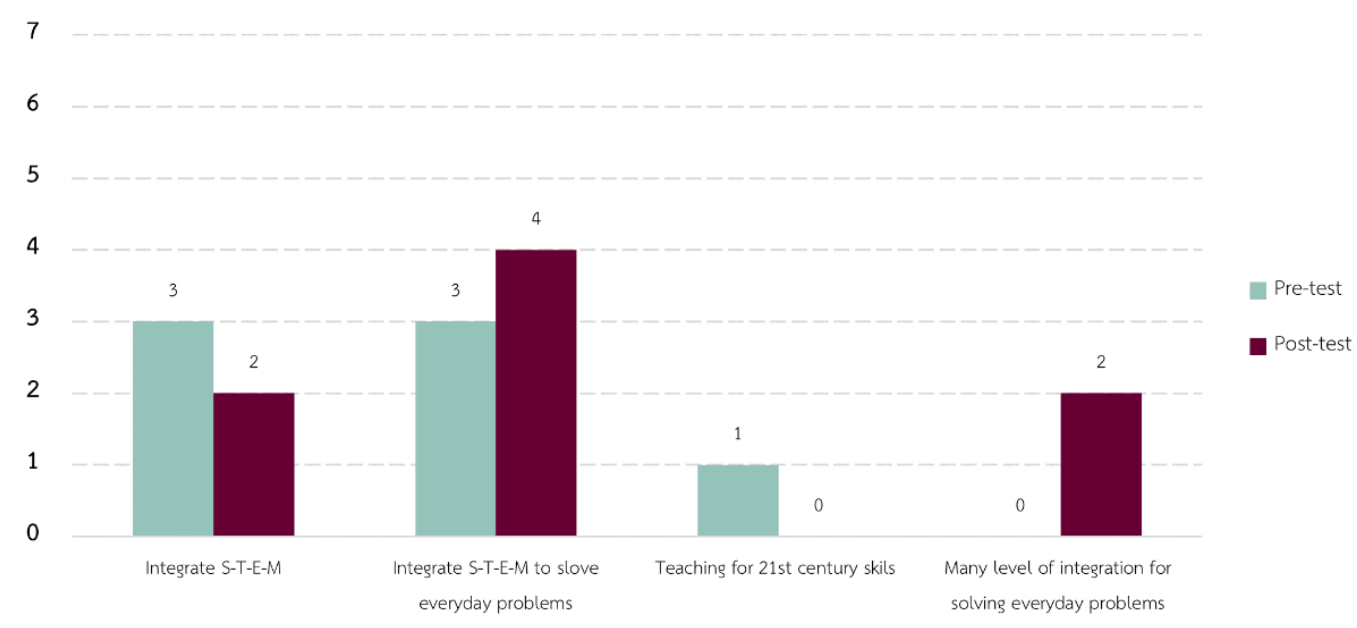

WHAT IS PURPOSE OF STEM EDUCATION?

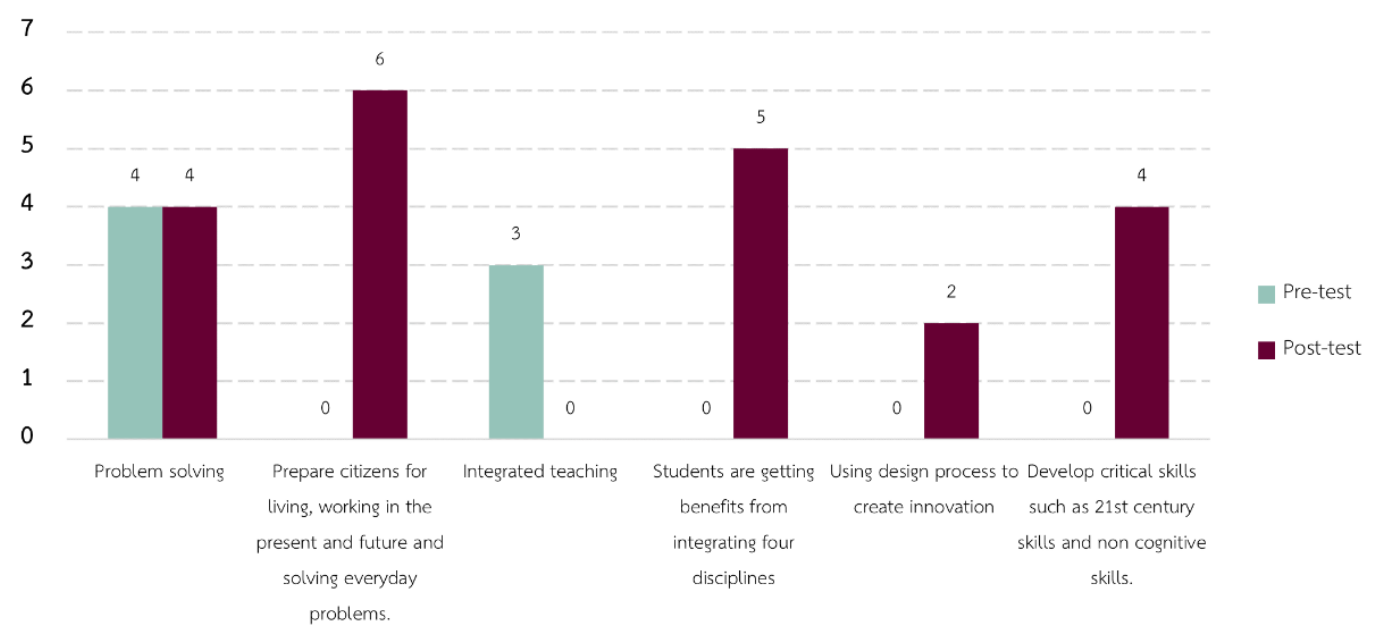

Figure 2. Student's response from pre- and post- surveys 


\section{HOW DOES STEM RELATE TO YOUR MAJOR?}

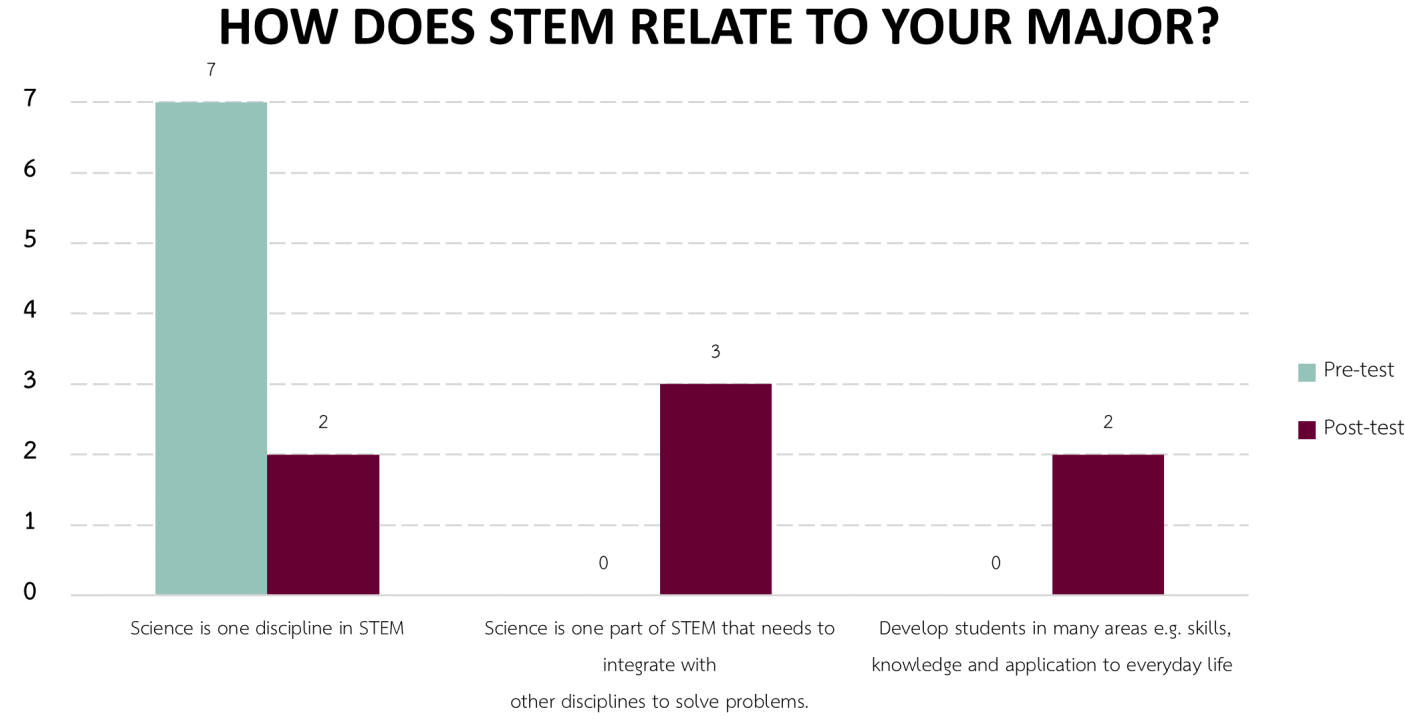

WHAT IS INTREGATION?

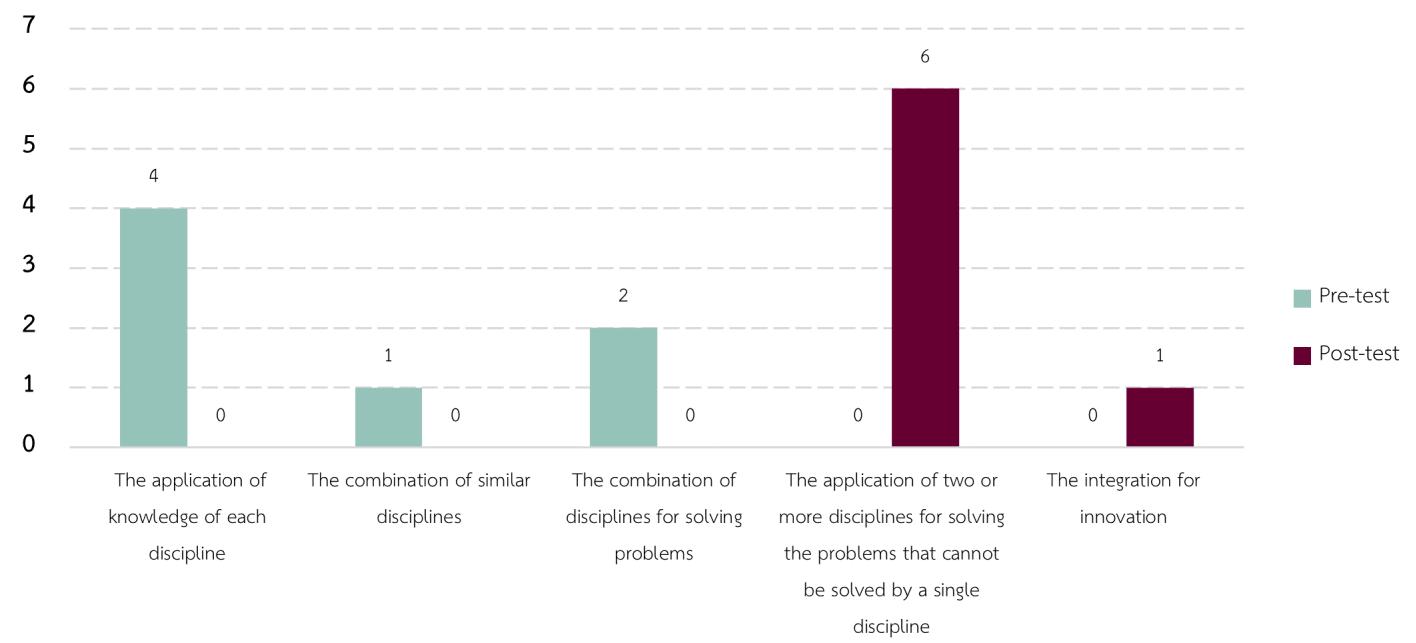

Draw a diagram to illustrate how they visualized S-T-E-M integration.

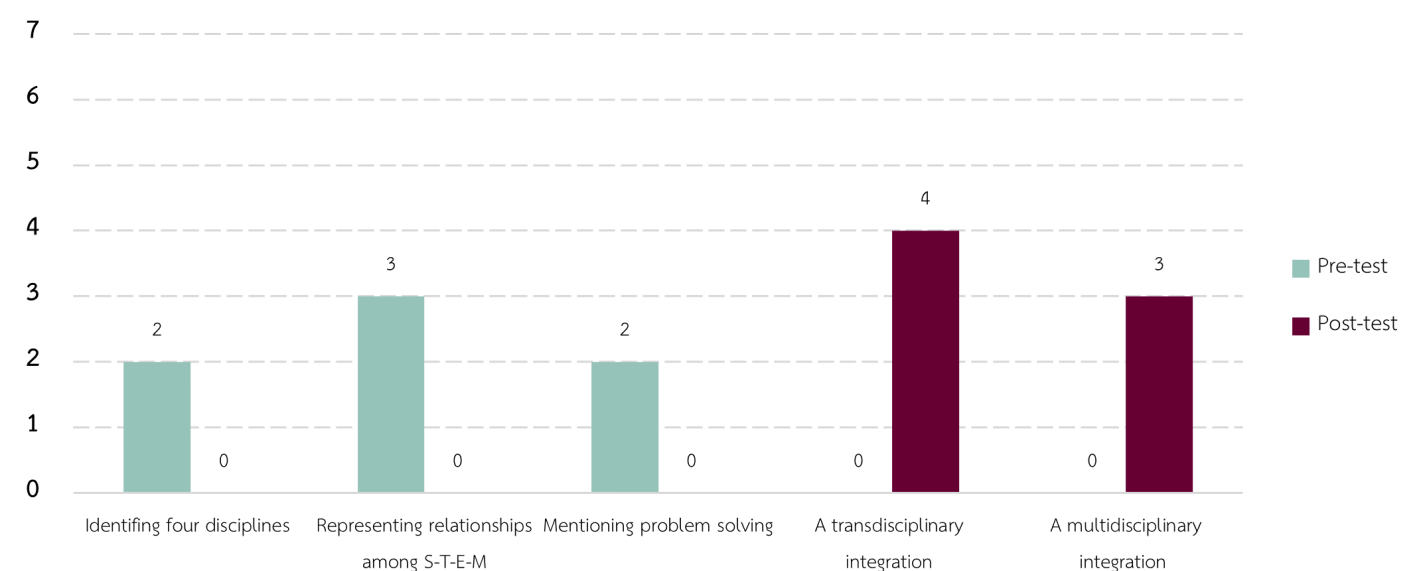

Figure 2 (continued). Student's response from pre- and post- surveys 


\section{WHEN SHOULD STEM BE TAUGHT?}

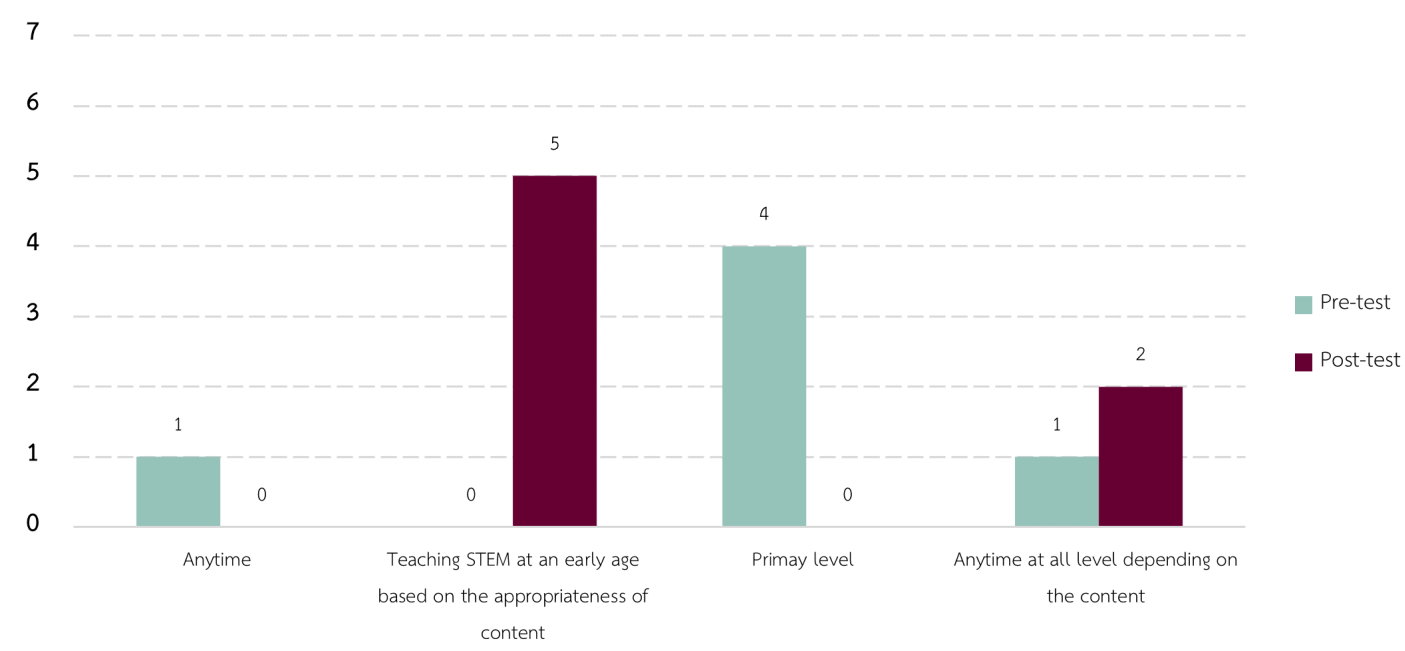

WHICH TEACHERS SHOULD TEACH STEM?

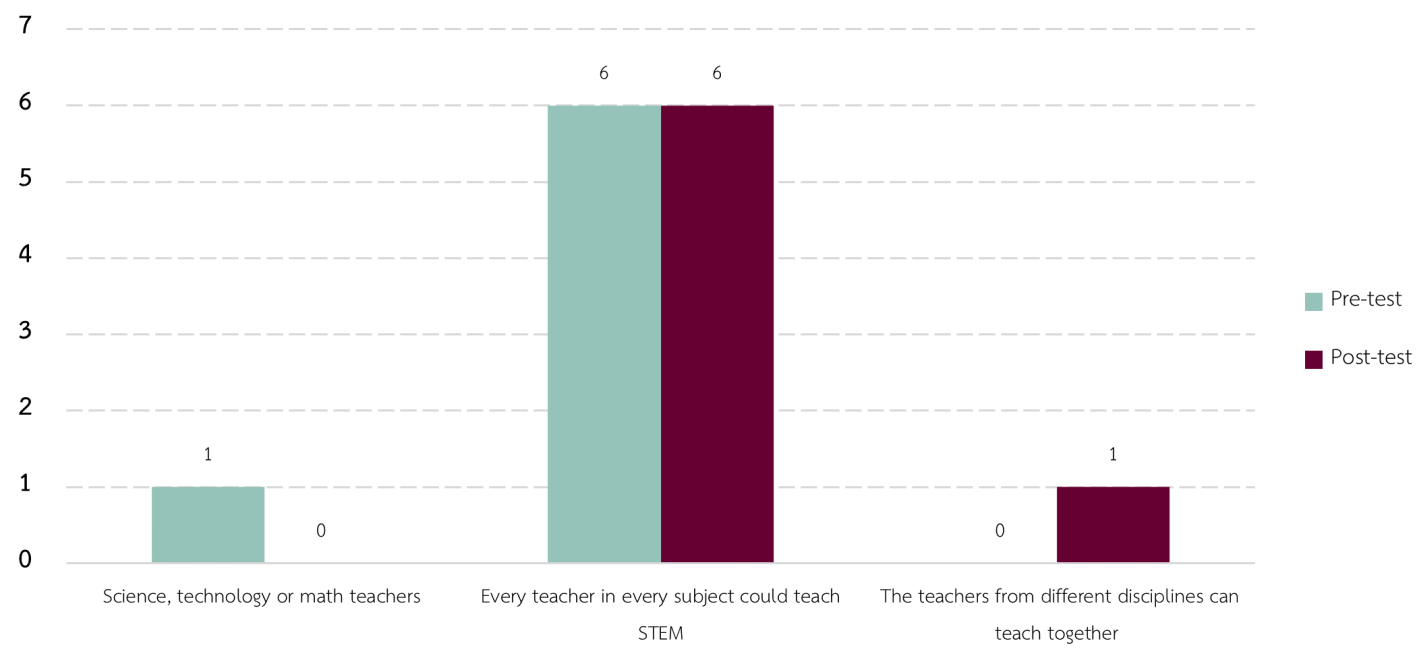

Figure 2 (continued). Student's response from pre- and post- surveys

Regarding the concept of STEM, the methods course helped all preservice teachers (7 participants) elaborate their understanding of STEM. They explained that STEM is not just integrating science, technology engineering, and mathematics, but STEM integrates science, technology engineering, and mathematics to solve everyday problems. A similar idea on solving everyday problems was found in the second survey question which participants were asked to identify the purpose of STEM education. In the pre-survey, 4 out of 7 participants said the purpose of STEM education is problem-solving. In the post-survey, 6 out of 7 participants identified the purpose of STEM education as to prepare citizens for living, working in the present and future and solving everyday problems. SC 7 is one of students who elaborated his idea about the purpose of STEM as his excerpt from post interview:

“Mainly, I didn't change my answer from the presurvey much but in the view that I have seen more things in STEM. From studying in this course [STEM methods course], I have seen clearly that the students will be aware of the importance and applications of the four disciplines. Studying with STEM allows students to see problems and find solutions. I think the students need to connect knowledge between these disciplines for solving problems. They can identify problems, analyze the problem solution and create prototype."

In response to the question, "How does STEM relate to your major?" all participants said in the pre-survey that science is one discipline in STEM. In the postsurvey, 3 out of 6 participants explained how STEM relates to their major by mentioning that science is one part of STEM that needs to integrate with other disciplines to solve problems. SC1 is one of the preservice teachers who changed her responses to this question. She clarified her idea in post interview: 
"Before this course [STEM methods course], I have heard the term "STEM". I personally think that STEM is bringing other subjects with science to solve problems. I think science is the main focus and science is the solution to the problems while other subjects are involved. After having learned this course, I can see other perspectives including engineering, mathematics, and technology which have different perspectives from science. Including processes or procedures that make it think that other disciplines have the same role in STEM as science. So, we can integrate four disciplines to solve the problems."

To elicit an understanding of what is integration in the pre-survey, 4 participants mentioned the ideas of the application of knowledge of each discipline. In the postsurvey, 6 participants clarified that integration is applying two or more disciplines for solving the problems that cannot be solved by a single discipline.

Moreover, the participants were asked to draw a diagram to illustrate how they visualized S-T-E-M integration. In the pre-survey, 3 participants showed the diagram which represented relationships between S-TE-M. In the post-survey, all diagrams showed the equally important S-T-E-M as a transdisciplinary integration (4 participants) and a multidisciplinary integration (3 participants). Interview with SC 4 helped the researchers to understand how he visualized S-T-E$\mathrm{M}$ integration:

"In the past, I thought that problem-solving in STEM need to separate each discipline to solve the same problem. Nevertheless, after this course [STEM methods course], I think that we should integrate all disciplines and then draw on the concepts of each discipline to solve the problem so that the solution will be more sustainable."

In response to the researcher question what do you mean by sustainable?

"If we solve the problem in a separate discipline, each discipline has a different view of the same problem. So, the solution may not be effective enough to meet the needs. However, once they are integrated, every discipline shares a common point of view. I think this is sustainable and effective problem solving."

The last questions (When should STEM be taught? and Which teachers should teach STEM?) were used to explore the participants' ideas about the appropriate time for STEM teaching and the appropriateness of STEM teachers. In pre-survey, the participants' idea is varied, but for the post-survey, all of them agree that we need to begin teaching STEM at an early age based on the appropriateness of the content. All participants mentioned in pre- and post-survey that every teacher in every subject could teach STEM. However, in the postsurvey, one participant mentioned that it would be better if the teachers from different disciplines can teach together.

\section{DISCUSSION AND CONCLUSION}

The information for developing the STEM course design model was reviewed. Integrated STEM is the main philosophy for STEM education. The STEM methods course design model in this study reinforced the idea of integrated STEM which was applied to encourage people to address authentic problems that cannot be solved with a single discipline, but require using the integration of the knowledge and processes of different STEM disciplines (Bybee, 2013; Nadelson \& Seifert, 2017; Urban \& Falvo, 2016). STEM skills are also promoted in this study as necessary for students to solve authentic, complex problems in a rapidly changing world (Bybee, 2010, 2013; Dearborn, 2017; Vasquez et al., 2013).

The framework and guiding principles of STEM education were developed to underpin the STEM methods course based on the idea of integrated STEM and the Thai Basic Education Core Curriculum. A range of STEM activities is presented. All preservice teachers were encouraged to design STEM lessons and activities that relate to daily life contexts. This practice may lead preservice teachers to realize the importance of preparing opportunities for their students to apply knowledge and skills to solve complex and multidimensional issues or problems (Bybee, 2013; National Research Council, 2000; Radloff \& Guzey, 2017; Vasquez et al., 2013).

The STEM methods course implementation showed that before the study, the participants had limited STEM understanding. According to the pre-survey, although they mentioned integration, they did not explain it in detail. This finding was consistent with the study of Pimthong and Williams (2020). In the post-survey, the participants illustrated integrating STEM in a transdisciplinary and multidisciplinary manner based on the problems that a single discipline cannot solve (Vasquez et al., 2013). According to how to teach STEM, in the pre-survey, the participants' ideas are diverse. This lack of clarity might be because they did not understand the position of their major area of study (science) in STEM. In the post-survey, the participants considered integrating S-T-E-M for teaching in an appropriate core content knowledge of each discipline and the interdisciplinary processes (English, 2016; Sanders, 2009; Urban \& Falvo, 2016). This study's implications indicate that it is vital for teacher educators to be concerned with the goals of integrated STEM practices for preservice teacher preparation programs.

This study's limitations are that there were only seven participants in the implementation phase and all of them were majoring in science teaching. Future research might examine the implementation of the developed methods course among preservice teachers from different disciplines. Furthermore, the preservice teachers had no opportunities to practice their teaching 
in an actual classroom due to the COVID-19 pandemic. Future studies should integrate an appropriate practice for preservice STEM teaching preparation programs, and so become the new normal.

Author contributions: All authors made substantial contributions to the article and participated in the drafting of the article. All authors read and approved the final manuscript.

Funding: Funding was provided by the Program to Prepare Research and Development Personnel, Science Education Division, Faculty of Education, Kasetsart University, Bangkok, Thailand.

Acknowledgements: Academic support was provided by the STEM Education Research Group, School of Education, Curtin University, Perth, WA, Australia

Declaration of interest: The authors declare that they have no competing interests.

\section{REFERENCES}

Ahn, Y. H., Cho, C.-S., \& Lee, N. (2013). Building information modeling: Systematic course development for undergraduate construction students. Journal of Professional Issues in Engineering Education and Practice, 139(4), 290-300. https:/ / doi. org/10.1061/(ASCE)EI.1943-5541.0000164

American Association for the Advancement of Science. (1990). The Nature of Science. http://www.project 2061.org/publications/sfaa/online/chap1.htm

Bartels, S. L., Rupe, K. M., \& Lederman, J. S. (2019). Shaping preservice teachers' understandings of STEM: A collaborative math and science methods approach. Journal of Science Teacher Education, 30(6), 666-680.

https:/ / doi.org/10.1080/1046560X.2019.1602803

Bell, B. (1993). Children's sciences, constructivism and learning in science. Deakin University.

Bell, D. (2016). The reality of STEM education, design and technology teachers' perceptions: A phenomenographic study. International Journal of Technology and Design Education, 26(1), 61-79. https:/ / doi.org/10.1007/s10798-015-9300-9

Blessinger, P., \& Carfora, J. M. (2015). Innovative approaches in teaching and learning: An introduction to inquiry-based learning for STEM programs. In P. Blessinger \& J. M. Carfora (Eds.), Inquiry-based learning for Science, Technology, Engineering, and Math (STEM) programs: A conceptual and practical resource for educators (Vol. 4, pp. 3-19). Emerald. https://doi.org/10.1108/ S2055-364120150000004001

Bybee, R. (2010). What is STEM education? Source: Science, New Series, 329(5995), 996. https:/ / doi.org/10.1126/science.1194998

Bybee, R. (2013). The case for STEM education: Challenges and opportunities. NSTA Press.

Chulavatnatol, M. (2013). STEM education Thailand and STEM ambassadors (In Thai). IPST, 42(185), 14-18.
Clavert, M., \& Paloposki, T. (2015). Implementing design-based learning in teaching of combustion and gasification technology. International Journal of Engineering Education, 31(4), 1021-1032.

Crippen, K. J., \& Archambault, L. (2012). Scaffolded inquiry-based instruction with technology: A signature pedagogy for STEM education. Computers in the Schools, 29(1-2), 157-173. https:/ / doi.org/10.1080/07380569.2012.658733

Dearborn, L. (2017). What are soft skills? STEMJOBS. http:/ / edu.stemjobs.com/what-are-soft-skills /

Driver, R., Asoko, H., Leach, J., Mortimer, E., \& Scott, P. (1994). Constructing scientific knowledge in the classroom. Educational Researcher, 23(7), 5-12. https:/ / doi.org/10.3102/0013189X023007005

Edutopia. (2008). Why teach with project-based learning? Providing students with a well-rounded classroom experience. http://www.edutopia.org/projectlearning-introduction

English, L. (2016). STEM education K-12: perspectives on integration. International Journal of STEM Education, 3(1), 3. https:/ / doi.org/10.1186/s40594-016-0036-1

English, L. (2017). Advancing elementary and middle school STEM education. International Journal of Science and Mathematics Education, 15(S1), 5-24. https:/ / doi.org/10.1007/s10763-017-9802-x

Fortus, D., Krajcik, J., Dershimer, R. C., Marx, R. W., \& Mamlok-Naaman, R. (2005). Design-based science and real-world problem-solving. International Journal of Science Education, 27(7), 855-879. https:/ / doi.org/10.1080/09500690500038165

Ganado, P. L. (2016). School to switch to Singapore maths approach. Times of Malta. https://www. timesofmalta.com/articles/view/20160802/local/ school-to-switch-to-singapore-maths-approach. 620737

Grant, M. M. (2002). Getting a grip on project-based learning: Theory, cases and recommendations. Meridian: A Middle School Computer Technologies Journal, 5(1), 1-17.

Hess, K., \& Hess, K. (2013). Working knowledge: STEM essentials for the 21st century. Springer. https: / / doi.org/10.1007/978-1-4614-3275-3

Honey, M. (2012). Design-based learning: A new paradigm for STEM education. https:/ / www.ibm.com/blogs / citizen-ibm/2012/03/design-based-learning-anew-paradigm-for-stem-education/

International Technology Education Association. (2007). Standards for technological literacy standards for technological literacy: Content for the study of technology (3rd ed.). International Technology Education Association.

Joffe, H. (2012). Thematic analysis. In D. Harper, \& A. R. Thompson (Eds.), Qualitative research methods in 
mental health and psychotherapy: A guide for students and practitioners (pp. 209-223). John Wiley \& Sons. https:// doi.org/10.1002/9781119973249.ch15

Johnson, C. C., Peters-Burton, E. E., \& Moore, T. J. (Eds.) (2016). STEM road map: a framework for integrated STEM education. Routledge. https://doi.org/ 10.4324/9781315753157

Kelley, T. R., \& Knowles, J. G. (2016). A conceptual framework for integrated STEM education. International Journal of STEM Education, 3(1), 11. https: / / doi.org/10.1186/s40594-016-0046-z

King, D., \& English, L. (2016). Engineering design in the primary school: applying stem concepts to build an optical instrument. International Journal of Science Education, 38(18), 2762-2794. https://doi.org/ 10.1080/09500693.2016.1262567

Kocabas, S., Ozfidan, B., \& Burlbaw, L. M. (2019). American STEM education in its global, national, and linguistic contexts. EURASIA Journal of Mathematics, Science and Technology Education, 16(1), em1810. https:/ / doi.org/10.29333/ ejmste/108618

Koul, R., Fraser, B., Maynard, N., Tade, M., \& Henderson, D. (2016). Science, Technology, Engineering and Mathematics (STEM) teaching to primary-school students: Some case studies. In R. Nata (Ed.), Progress in education (pp. 97-118). Nova Science Publishers, Inc.

Lópezleiva, C., Roberts-Harris, D., \& Von Toll, E. (2016). Meaning making with motion is messy: developing a STEM learning community. Canadian Journal of Science Canadian Journal of Science, Mathematics and Technology Education, 16(10), 169-182. https:/ / doi.org/10.1080/14926156.2016.1166293

Lovell-Troy, L. A., \& Eickmann, P. (1992). Course design for college teachers. Educational Technology Publications.

Murphy, T. (2011). STEM Education--It's elementary. https: / / www.usnews.com/news/articles/2011/0 8/29/stem-education--its-elementary

Nadelson, L. S., \& Seifert, A. L. (2017). Integrated STEM defined: Contexts, challenges, and the future. Journal of Educational Research, 110(3), 221-223. https:/ / doi.org/10.1080/00220671.2017.1289775

Nadelson, L. S., Callahan, J., Pyke, P., Hay, A., Dance, M., \& Pfiester, J. (2013). Teacher STEM perception and preparation: Inquiry-based STEM professional development for elementary teachers. The Journal of Educational Research, 106(2), 157-168. https: / / doi.org/10.1080/00220671.2012.667014

National Academy of Engineering and National Research Council. (2009). Engineering in K-12 education. National Academies Press. http:/ / doi.org/10.17226/12635

National Research Council. (1996). National science education standards. National Academies Press.
National Research Council. (2000). Inquiry and the national science education standards. National Academies Press.

National Research Council. (2011). Successful K-12 STEM education: Identifying effective approaches in science, technology, engineering, and mathematics. Committee on highly successful science programs for K-12 science education. Board on Science Education and Board on Testing and Assessment, Division of Behavioral and Social Sciences and Education. The National Academies Press.

National Science Foundation. (2007). National action plan for addressing the critical needs of the U.S. science, technology, engineering, and mathematics education system. NSB 07-114. National Science Foundation.

National Science Technology and Innovation Policy Office. (2015). Initiatives. http:/ / www.sti.or.th/en content.php?content_type $=5$

Office of the Prime Minister. (2017). The twelfth national economic and social development plan (2017-2021). Bangkok, Thailand.

Oliva, P. F. (1982). Developing the curriculum. Little, Brown.

Oliva, P. F. (2009). Developing the curriculum (7th ed.). Pearson/Allyn and Bacon.

Park, D.-Y., Park, M.-H., \& Bates, A. B. (2016). Exploring young children's understanding about the concept of volume through engineering design in a STEM activity: A case study. International Journal of Science and Mathematics Education, 16, 275-294. https:/ / doi.org/10.1007/s10763-016-9776-0

Pimthong, P., \& Williams, P. J. (2020). Preservice teachers' understanding of STEM education. Kasetsart Journal of Social Sciences, 41, 289-295.

Posner, G. J., \& Rudnitsky, A. N. (1994). Course design: A guide to curriculum development for teachers (4th ed.). Longman.

Prinsley, R., \& Johnston, E. (2015). Transforming STEM teaching in Australian primary schools: Everybody's business. Canberra, ACT Australia.

Radloff, J., \& Guzey, S. (2016). Investigating preservice STEM teacher conceptions of STEM education. Journal of Science Education and Technology, 25(5), 759-774. $\quad$ https://doi.org/10.1007/s10956-0169633-5

Radloff, J., \& Guzey, S. (2017). Investigating changes in preservice teachers' conceptions of stem education following video analysis and reflection. School Science and Mathematics, 117(3-4), 158-167. https:/ / doi.org/10.1111/ssm.12218

Royal Thai Embassy, W. D. C. (2017). Thailand 4.0. http:/ / thaiembdc.org/thailand-4-0-2/

Sanders, M. (2009). STEM, STEM education, STEMmania. The Technology Teacher, 69(4), 20-27. 
Sanders, M. (2012). Integrative STEM education as "best practice". In The Technology Education Research Conference (pp. 4). Queensland.

Sanders, M. (2015). The original 'integrative STEM Education'; definition: explained. Virginia.

Schmidt, K. M., \& Kelter, P. (2017). Science fairs: A qualitative study of their impact on student science inquiry learning and attitudes toward STEM. Science Educator, 25(2), 126-132.

Schmidt, M., \& Fulton, L. (2016). Transforming a traditional inquiry-based science unit into a STEM unit for elementary pre-service teachers: A view from the trenches. Journal of Science Education and Technology, 25(2), 302-315. https:/ / doi.org/10.1007 /s10956-015-9594-0

Sherman, S. J., \& Sherman, R. S. (2004). Science and science teaching: Methods for integrating technology in elementary and middle schools (2nd ed.). Houghton Mifflin Company.

Shernoff, D. J., Sinha, S., Bressler, D. M., \& Ginsburg, L. (2017). Assessing teacher education and professional development needs for the implementation of integrated approaches to STEM education. International Journal of STEM Education, 4(1), 13. https:/ / doi.org/10.1186/s40594-017-00681

Sias, C. M., Nadelson, L. S., Juth, S. M., \& Seifert, A. L. (2017). The best laid plans: Educational innovation in elementary teacher generated integrated STEM lesson plans. The Journal of Educational Research, 110(3), 227-238. https:/ / doi.org/10.1080/00220671. 2016.1253539

Stohlmann, M., Moore, T. J., McClelland, J., \& Roehrig, G. H. (2011). Impressions of a middle grades STEM integration program. Middle School Journal, 43(1), 32-40.

https:/ / doi.org/10.1080/00940771.2011.11461791

Talley, T. (2017). The STEM coaching handbook: Working with teachers to improve instruction. Routledge. https:/ / doi.org/10.4324/9781315625003

The Buck institute for Education (BIE). (2014). Why PBL? http:/ / bie.org/about/why_pbl
The Cambridge english dictionary. (2018). Mathematics meaning.

https:/ / dictionary.cambridge.org/dictionary/eng lish/mathematics?q=Mathematics

The Institute for the Promotion of Teaching Science and Technology (IPST). (2017). A path to success for STEM education in Thailand. IPST.

The National News Bureau of Thailand. (2017). Develop Thai citizen for Thailand 4.0. http:/ / thainews.prd. go.th/website_th/news/news_detail/TNRPT6005 060010008

Thomas, J. W. (2000). A review of research on project-based learning. http://www.bobpearlman.org/BestPrac tices/PBL_Research.pdf

Tyler, R. W. (1971). Basic principles of curriculum and instruction. University of Chicago Press.

Urban, M. J., \& Falvo, D. A. (2016). Preface. In M. J. Urban \& D. A. Falvo (Eds.), Improving K-12 STEM Education Outcomes through Technological Integration (pp. 498). IGI Global. https:/ / doi.org/10.4018/9781-4666-9616-7

Vartiainen, H., Liljeström, A., \& Enkenberg, J. (2012). Design-oriented pedagogy for technologyenhanced learning to cross over the borders between formal and informal environments. Journal of Universal Computer Science, 18(15), 2097-2119. https:// doi.org/10.3217/jucs-018-15-2097

Vasquez, J. A., Sneider, C., \& Comer, M. (2013). STEM lesson essentials, grades 3-8: Integrating science, technology, engineering, and mathematics. Heinemann.

Virginia Tech. (2018). Integrative STEM education. https:/ / liberalarts.vt.edu/departments-andschools/school-of-education/academicprograms/integrative-stem-education.html

Williams, P. J. (2011). Focus on design in technology - Book A. User Friendly Resources.

Won, S. G. L., Evans, M. A., Carey, C., \& Schnittka, C. G. (2015). Youth appropriation of social media for collaborative and facilitated design-based learning. Computers in Human Behavior, 50, 385-391. https:// doi.org/10.1016/j.chb.2015.04.017

\section{http://www.ejmste.com}

